\title{
NATUREZA E EXTENSÃO DO METASSOMATISMO DAS ROCHAS ENCAIXANTES DA PORÇÃO ORIENTAL DO MACIÇO ALCALINO POÇOS DE CALDAS: CONSIDERAÇÕES PRELIMINARES
}

V.A.Janasi ${ }^{1}$

Durante o desenvolvimento de estudos petrológicos em rochas granitóides préCambrianas situadas a leste do maciço alcalino cretácico de Poços de Caldas, foram reunidas evidências de campo, geoquímicas e principalmente texturais sobre a natureza e extensão do metassomatismo associado àquela intrusão.

Contrariamente a algumas proposições encontradas na literatura, o caráter pobre em quartzo de algumas rochas "granitóides" encaixantes não pode ser atribuído a fenitização, mas constitui feição composicional primária encontrada no maciço mangeritico São Pedro de Caidas (SPC) e no maciço sienítico Pedra Branca (PB). As principais evidências de metassomatismo são texturais e mineralógicas, e incluem:

- surgimento de manchas de anfibólio azul-escuro artvedsonítico substituindo o anfibólio original (hornblenda edenítica em PB ou hastingsítica em SPC), ao longo de fraturas, clivagens e contatos; no maciço PB, observa-se adicionalmente alguma substituição do piroxênio original (dipsídio) e da biotita, e a arfvedsonita pode ser acompanhada por egirina titanffera;

- pseudomorfismo parcial a total da hornblenda por aglomerados formados por pequenos cristais de biotita verde, carbonato, epidoto e opacos (ocasionalmente acompanhados de proporções variadas de actinolita, clorita, albita, quartzo, muscovita, e mesmo de alguma arfvedsonita);

- aparecimento de massas irregulares formadas por intercrescimentos de carbonato, egirina (em parte prismática, mas principalmente em feixes de cristais aciculares) e quartzo;

- carbonatação e saussuritização intensas;

- aparecimento de abundantes inclusões fluidas em quartzo e feldspatos.

$\overline{1}$ Departamento de Mineralogia e Petrologia, Instituto de Geociências, USP. 
Esses efeitos são observados, em graus variados, em amostras situadas por uma distância de até $2 \mathrm{~km}$ do contato externo do maciço alcalino. Por toda essa faixa, as rochas mangerfticas-charnoquiticas do maciço SPC (que caracteristicamente são verde-escuras quando frescas) têm cor verde-claro acinzentada (localmente, até vermelho-arroxeada), que é comum em outras regiōes onde elas foram afetadas por hidratação pós-magmática (e.g., durante processos "retrometamórficos").

Uma amostra possivelmente derivada de rochas do maciço SPC, encontrada em contato direto com fonolitos do maciço Poços de Caldas, tem cor esbranquiçada, e mostra efeitos metassomáticos ainda mais pronunciados. Estão ausentes anfibólios ou piroxênios cálcicos, e o mineral máfico principal, uma biotita de cor alaranjada, está fortemente recortado por fraturas largas preenchidas por quartzo e opacos. Cordões preenchidos por arfvedsonita, epidoto e carbonato preenchem fraturas na rocha, ou circundam os grãos de quartzo.

Apesar das evidências claras de introdução de material externo, as mudanças químicas provocadas pelo fenômeno são, em geral, praticamente nulas no que se refere aos elementos maiores. Modificações nos conteúdos de elementos traços, contudo, são sugeridas por análises químicas de mangeritos, que podem ter sido levemente enriquecidos em $\mathrm{Sr}, \mathrm{Rb}, \mathrm{e}$ possivelmente ETR, entre outros.

As evidências texturais e mineralógicas indicam que o processo foi controlado pela passagem de soluções alcalinas através de microfraturas nas rochas, cujo registro petrográfico são vênulas de preenchimento compostas por carbonato ( \pm epidoto e albita, quando dentro de feldspatos). A composição do fluido metassomático, possivelmente rico em $\mathrm{F}$ e $\mathrm{Cl}$, deverá ser caracte:izada futuramente a partir da análise das inclusões fluidas em quartzo e feldspatos, algumas delas exibindo inclusões sólidas salinas que mostram hábitos variados ao microscópico eletrônico. 